Salud y Tecnología Veterinaria, 3(1), 10-12

\title{
Comparación del Sexaje por PCR usando muestras de ADN de sangre y plumas de aves domésticas
}

\author{
Saldaña Katherine ${ }^{1 *}$ Hung Armando ${ }^{1}$ \\ ${ }^{1}$ Facultad de Medicina Veterinaria y Zootecnia, Universidad Peruana Cayetano Heredia, Lima-Perú \\ * katherine.saldana.m@upch.pe \\ Aceptado para publicación: 28 de Setiembre de 2015
}

\begin{abstract}
RESUMEN
Objetivo: Comparar dos métodos de obtención de ADN usando muestras de sangre y de plumas de patos y gallinas. Metodología: Se utilizaron muestras de 13 aves: 10 patos ( 7 hembras, 2 macho; 1 sexo indefinido) y 3 pollos (2 hembras; 1 macho). Se extrajo ADN de sangre usando QIAamp ARN Mini Kit y para las muestras de plumas se utilizó el protocolo con proteinasa K. Se amplificó mediante PCR usando el protocolo y los primers P8 y P2.

Resultados: Los resultados mostraron una mayor cantidad de ADN en las muestras de plumas y solo en estas muestras se pudo apreciar con claridad las bandas en la electroforesis. Por lo tanto se sugiere que el sexaje no solo de aves domésticas si no también silvestres que no cuentan con dimorfismo sexual puede realizarse fácilmente con plumas en lugar de muestras de sangre, obteniendo resultados iguales o mejores sin la necesidad de un procedimiento invasivo para conseguir la muestra.
\end{abstract}

\section{INTRODUCCIÓN}

En mamíferos, una hembra tiene pares cromosómi$\cos \mathrm{XX}$, mientras que un macho XY. Todo embrión por defecto es hembra, sin embargo la acción del gen SRY presente en el cromosoma Y, promueve el desarrollo de los testículos en los machos. Esta característica puede ser de utilidad para el diagnóstico de sexo usando muestras de ADN. Por ejemplo, en alpacas se amplificó el gen SRY para determinar sexo a partir de muestras de sangre (Arias \& Huanca, 2009).

El genoma de las aves cuenta con dos cromosomas sexuales $\mathrm{Z}$ y W. Las aves hembra son heterogaméticas (ZW) y los machos son homogaméticos (ZZ). Ambos cromosomas sexuales conservan el gen CHD. Usando los primers P2 y P8 se amplifica mediante PCR porciones del gen CHD. Luego de realizar la electroforesis, el producto se muestra con una banda de 345 pares base para la porción CHD-W y de 362 pares base para la porción CHD-Z (Griffiths et al., 1998).

\section{MATERIALES Y METODOS}

Se recolectaron muestras de sangre y de pluma de 13 aves de granja (7 patos hembra, 2 patos machos, 1 pato de sexo indefinido, 2 gallinas y 1 gallo).

Para la extracción de ADN de las muestras de sangre se utilizó el QIAamp ARN Mini Kit, mientras que para las muestras de plumas se utilizó un método que consistió en cortar $1 \mathrm{~cm}$ de la porción terminal de las plumas, estas fueron colocadas en tubos eppendorf y luego se les colocó en $500 \mu 1$ de un buffer de lisis $(50 \mathrm{mM}$ Tris- $\mathrm{HCl}, \mathrm{pH} 8,20 \mathrm{mM}$ EDTA, $2 \%$ SDS) y $10 \mu l$ de proteinasa K. Los tubos fueron mezclados en el vortex por 10 segundos y luego llevados a incubación a $56^{\circ} \mathrm{C}$ durante toda la noche. Al día siguiente los tubos fueron homogenizados en el vortex por algunos segundos y luego centrifugados a 12000 RPM por 10 minutos y el sobrenadante fue colocado en tubos limpios desechando los restos conteniendo el raquis de las plumas. A continuación, se purificó el ADN con $500 \mu 1$ de fenol:cloroformo:isosamyl alcohol (25:24:1).Se agitó la mezcla en el vortex y centrifugó a 10000 RPM por 5 minutos. Después se agregó $50 \mu 1$ de $\mathrm{NaCl}$ a una concentración de $2 \mathrm{M}$ y $100 \mu$ de etanol 
se volvió a centrifugar a 10000 RPM por 5 minutos observando que se forme un pellet en el fondo del tubo, se lavó con $500 \mu 1$ etanol al $70 \%$ y por último se resuspendió el pellet en $50 \mu \mathrm{l}$ de agua destilada (Bello et al., 2001). El ADN obtenido de las muestras de sangre y plumas fue utilizado como molde para un PCR usando primers para el cromosoma CHD P8 5'-CTCCCAAGGATGAGRAAYTG-3' y P2 5'-TCTGCATCGCTAAATCCTTT-3' (Griffiths et al., 1998).

\section{RESULTADOS}

Los productos de extracción de ADN a partir de las muestras fueron analizadas en un espectrofotómetro (NanoDrop) para determinar la cantidad de ADN obtenido en cada muestra.
TABLA 2. Concentraciones de ADN obtenidas a partir de muestras de sangre usando el método de fenol-cloroformo mediante espectrofotometría.

\begin{tabular}{|c|c|c|}
\hline $\begin{array}{c}\text { Muestra de } \\
\text { plumas }\end{array}$ & ng/ $\boldsymbol{\mu l}$ & $\mathbf{A 2 6 0 / A 2 8 0}$ \\
\hline 1 & 234.8 & 1.88 \\
\hline 2 & 262.2 & 1.85 \\
\hline 3 & 51.2 & 1.73 \\
\hline 4 & 63.1 & 1.72 \\
\hline 5 & 126.5 & 1.83 \\
\hline 6 & 180.7 & 1.86 \\
\hline 7 & 135.7 & 1.81 \\
\hline 8 & 55.0 & 1.69 \\
\hline 9 & 51.1 & 1.68 \\
\hline 10 & 28.6 & 1.58 \\
\hline 11 & 22.0 & 1.58 \\
\hline 12 & 373.5 & 1.94 \\
\hline 13 & 1437.8 & 1.98 \\
\hline
\end{tabular}

TABLA 1. Concentraciones de ADN obtenidas a partir de muestras de sangre usando un kit comercial mediante espectrofotometría.

\begin{tabular}{|c|c|c|}
\hline $\begin{array}{c}\text { Muestra de } \\
\text { sangre }\end{array}$ & $\mathbf{n g} / \boldsymbol{\mu l}$ & $\mathbf{A 2 6 0 / A 2 8 0}$ \\
\hline 1 & 46.6 & 1.79 \\
\hline 2 & 7.5 & 1.66 \\
\hline 3 & 9.1 & 1.54 \\
\hline 4 & 7.5 & 1.46 \\
\hline 5 & 12.4 & 1.31 \\
\hline 6 & 8.3 & 1.57 \\
\hline 7 & 4.9 & 1.70 \\
\hline 8 & 3.9 & 1.57 \\
\hline 9 & 2.3 & 1.73 \\
\hline 10 & 3.5 & 1.67 \\
\hline 11 & 3.8 & 1.66 \\
\hline 12 & 4.1 & 1.66 \\
\hline 13 & 4.5 & 1.54 \\
\hline
\end{tabular}

Luego de la amplificación por PCR se observó los resultados a través de una electroforesis en gel de agarosa al 2\%, de las cuales solo 3 muestras de ADN a partir de sangre fueron visibles, mientras que todas las muestras de plumas mostraron resultados visibles.

En 10 de las 13 muestras de plumas se observó una banda alrededor de los 300 pares base estas muestras concordaron con los datos recogidos asegurando que estos especímenes eran hembras. En cuanto a las muestras de machos no se observó ninguna banda. También se corrió un agar con una muestra de hembra, una muestra de macho y una muestra problema; encontrando que el espécimen problema concordaba con las muestra de hembra.

Las concentraciones de ADN obtenidas en las muestras de sangre resultaron ser menores de las esperadas, en otros estudios se utilizaron concentraciones mayores a $25 \mathrm{ng} / \mu \mathrm{L}$ (Liza et al., 2008); sin embargo los métodos de extracción utilizados difieren y podrían ser el causante de tan bajas concentraciones de ADN.

Por otro lado las muestras de plumas mostraron altas concentraciones de ADN lo que permitió la confirmación de sexo de los especímenes y la determinación de la muestra problema. Tal como lo 
describió Bello et al., 2001 las muestras mostraron mayor cantidad y calidad de ADN que permitía una fácil observación en el gel de agarosa.

\section{DISCUSIÓN}

Los resultados de la tabla 1 muestran una mayor cantidad de ADN en las muestras de plumas en comparación de las muestras de sangre.

No se observó la diferencia entre hembras y machos, se esperaba una banda a 345 bp en hembras y una banda a 362 bp en los machos. Sin embargo se observó que las muestras de machos no mostraban ninguna banda en la electroforesis.

Se encontró que con el método de extracción de ADN de plumas utilizado (Bello et al., 2001) se obtenía mayor cantidad de ADN que en las muestras de sangre usando un Kit comercial. Con esto se concluye que en aves con limitado dimorfismo sexual el sexaje puede realizarse usando muestras poco invasivas como son las plumas y que los resultados serán igual de efectivos que en una muestra de sangre usando un kit comercial.

\section{LITERATURA CITADA}

Arias, N., \& Huanca, W. (2009). Un método para el sexaje por ADN de alpaca amplificando el gen SRY mediante PCR. Revista de Investigaciones Veterinarias del Perú, 20(2), 203-207.

Bello, N., Francino, O., \& Sánchez, A. (2001). Isolation of genomic DNA from feathers. Journal of Veterinary diagnostic investigation, 13(2), 162164.

Griffiths, R., Double, M. C., Orr, K., \& Dawson, R. J. (1998). A DNA test to sex most birds. Molecular ecology, 7(8), 1071-1075.

Liza, R., Maturrano, H., \& Rosadio, A. (2008). Determinación del sexo por ADN en cinco especies de guacamayos. Revista de Investigaciones Veterinarias del Perú, 19(1), 31-36. 